\title{
Causes of Poor Academic Performance among Omani Students
}

\author{
Manizheh Alami (Corresponding author) \\ Salalah College of Technology, Sultanate of Oman \\ E-mail: manizheh.alami@yahoo.com
}

Received: January 28, 2016 Accepted: February 23, 2016 Published: March 3, 2016

doi:10.5296/ijssr.v4i1.8948

URL: http://dx.doi.org/10.5296/ijssr.v4i1.8948

\begin{abstract}
Nowadays, poor academic performance is among the main concerns of teachers, syllabus designers, curriculum developers and the whole educational body. The issue becomes worse in non-English speaking countries where the medium of instruction at colleges/ universities is English but students are exposed to English for a limited number of hours before beginning their study at college/university. To answer the question 'what are the causal factors that affect students' poor performances in non-English speaking countries like Oman? 151 essays written by students who enrolled for post foundation program at Salalah College of Technology were examined carefully. The factors involved in students' low academic achievements categorized into four macro groups; student-related factors, teacher- related factors, family- related factors and some other factors such as marriage, health problem, toxic friendships and transportation problem. The findings show that while student-related factors have the highest impact on students' performance, teacher-related factors had the lowest effect.
\end{abstract}

Keywords: Academic performance, student- related factors, Teacher-related factors, Family-related factors

\section{Introduction}

Understanding the goals of education and students' needs are necessary for an educational system to prosper. Surfing in the Internet and googling, we would come across ample number of articles and studies conducted to find out the factors that have impact on students' academic performance in different contexts and countries (Cascio 2015; Rahamneh, 2012). The findings yield some prominent factors among which are: poor teaching method, improper evaluation instruments, stress and emotional factors like feeling towards teacher, subject and 
learning environment and the gap between materials used for teaching and the students' needs.

Oman as a society, where English functions as second language, is not exceptional and faces the problem of low academic performance of the students. English is the medium of instruction in Oman post school / higher education institutions. The studies on ELT in Oman show that the vast majority of the students who finish high school (grade 12) and join different public and private higher education institutions are unable to use language to fulfill their social, personal, academic, and career needs effectively and appropriately (Al-Issa, 2009b).

Bearing in mind that majority of Omani high school graduates have a limited understanding of the expectations of the higher education system, it is not unpredictable to see the students who are not interested in participating classroom discussion, finding the subject/course boring, being absent frequently and get low marks in exams.

\section{Statement of the Problem}

There are internal and external factors that influence a student's academic performance. Thus, identifying these causes and getting to the root of them contributes to the betterment of students' academic performance dramatically. Unlike previous studies that approached the problem from teachers and/or academicians' point of view, the current study is a student oriented research in nature where the aim is to investigate the causes of poor academic performance from students' perspective. The collected data constitutes the comments and ideas of Omani students who study at Post Foundation level in Salalah College of Technology. The findings can contribute to eliminate all negative factors that affect academic performance.

\section{Objectives of the study}

Identifying where specific poor performance factors come from and how they intertwine with each other in various learning settings attracted the attention of academicians in the recent years. The present study is an attempt to explore the possible factors that may correlate in meaningful ways with the poor academic performance of Omani students at Salalah College of Technology (SCT). In other words, this study sought to answer the following questions:

(1) What student-related factors could be the causes of SCT students' poor academic performance?

(2) What teacher- related factors contribute to the low academic performance of students at SCT?

(3) What family-related factors cause SCT students perform academically poor?

(4) What are other factors that affect SCT students' low achievement? 


\section{Literature Review}

Given the fact that any student can have poor academic performance, the trouble appears critical when this becomes a trend. There are various reasons for students' poor academic performance based on the geographical area they are living in, students' cultural and historical background, the educational approaches and the common knowledge of students.

Siqueira and Juliana Gurge-Giannetti (2011, p. 79) define poor school performance (PSP) "as a school achievement below the expected for a given age, cognitive skills, and schooling". In a review study SiqueiraI, \& Juliana Gurge-GiannettilI classify the causes of PSP to two macro groups; 1) pedagogical difficulties and 2) diseases and associated disabilities. They believe that pushing students beyond their capabilities, skills and interest might lead to lack of interest, demotivation and distraction which in turn results in frustration, failure, low self-esteem besides family and school stress.

Karande and Kulkarni (2005) categorize the factors that affect learners performance into three groups; biological (student- born factors), psychological and social. They believe that biologically some students are below average in IQ among their peer age group. From psychological perspective we need to know whether our students are actually ready to learn and/ or like to learn. And socially, is the environment conducive and stimulating enough for ideal learning? Do students have access to necessary materials that could help them to improve and learn better? Karande and Kulkarni (2005, p. 961) in their study propose several reasons for children's low performance among which are medical problems, below average intelligent, specific learning disability, emotional problems and environmental causes. They believe that to solve this multi-varied and cross-linked problem, the focus should move from the class to the family, to the environment and to the social world of students.

Rahmaneh (2012) investigates the causes of poor academic achievement among the students of the main stages in selected schools in the province of Al-Balqa, Jordan. 100 teachers were selected randomly to fill in a 30- item questionnaire. The results of her study show that the reason for low academic performance fall under the following themes: focus of the student $(89.60 \%)$ was the first place followed by the school hub $(79.00 \%)$ followed by the family

Roche et. al (Cited in Al-Mahrooqi \& Denman, 2015) suggest that all foundation programs in Oman should include an orientation program that explicitly draws newly enrolled students' attention to differences between high school and university classrooms, participating in relation to assessment( the use of criteria -based assessment and pass/fail policies), classroom practice ( that students will be required to actively participate i.e., produce spoken and written English rather than memorize passages) and the expectations of students outside classroom ( e.g. students will be expected to read material outside the class). Such formal orientation program may be the first step to addressing Omani students' poor performance.

\section{Research Design}

Per SCT curriculum, English Technical Writing II (ENTW 1200) is offered in post foundation program to improve students' expository writing skill. For mid-semester exam, second semester Academic year 2014-2015, SCT students who have already been instructed 
to write a 5-paragraph cause or effect essay, are given two topics and are asked to elaborate on one of the topics. To pursue the objectives of this study, students' essays were collected upon receiving approval from level coordinator. The essays with 'Causes of poor performance' topic were separated and analyzed for the purpose of this study

\subsection{Population}

The targeted population constitutes students who enrolled for post foundation program and took English Technical Writing II (ENTW 1200) course in second semester, Academic year 2014-2015. 180 essays were collected from among which 151 essays on "causes of poor performance" were analyzed to find out the prominent factors that affect students' low performance.

\subsection{Findings}

Examining 151 essays written by SCT students at post foundation level for Mid-Semester exam revealed that the factors involved in the poor academic performance falls into four macro categories; student-related factors $(76.72 \%)$, teacher-related elements $(5.40 \%)$, family -related causes $(8.37 \%)$ and other factors like bad friends, marriage, having job, health problem, transportation problem and financial problem $(9.49 \%)$. Table 1 presents the various types of factors that might lead to low academic performance and their percentage.

Table1. Summary of macro causes for students poor performance

\begin{tabular}{cc}
\hline Type of factor & percentage \\
\hline Student-related factors & $76.72 \%$ \\
Family-related factors & $8.37 \%$ \\
Teacher-related factors & $5.40 \%$ \\
Other factors & $9.49 \%$ \\
\hline
\end{tabular}

As it is shown in the above table, the main reason for the poor performance pertains to the students and their incompetency in achieving academic success. Whereas teachers' role in students' academic failure is not prominent, the role of factors such as marriage, health problem, transportation, financial problem in students' failure are more prominent than family- related causes.

\subsubsection{Student-Related Factors}

Table 2 presents the different types of student-related problems and their percentage in hierarchical order. 
Table 2. Summary of student-related causes

\begin{tabular}{|c|c|}
\hline cause & Percentage \\
\hline Not studying/ not reviewing lessons at home & $16.50 \%$ \\
\hline $\begin{array}{l}\text { Being absent frequently/ Not attending classes } \\
\text { regularly }\end{array}$ & $15.04 \%$ \\
\hline $\begin{array}{l}\text { - not understanding subject/ finding subject difficult } \\
\text { and boring } \\
\text { - Feeling sleepy in classroom }\end{array}$ & $6.79 \%$ \\
\hline Not focusing while teacher teaches & $6.31 \%$ \\
\hline Coming late to class/ exam & $5.58 \%$ \\
\hline $\begin{array}{l}\text { - Playing with mobile } \\
\text { - } \quad \text { Do not do homework/ assignments at home }\end{array}$ & $5.09 \%$ \\
\hline Laziness & $4.61 \%$ \\
\hline Dislike to study & $4.36 \%$ \\
\hline Not understanding the teacher's language & $3.64 \%$ \\
\hline Talking in classroom & $2.91 \%$ \\
\hline Having problem with teacher/ dislike teacher & $2.42 \%$ \\
\hline Having no plan for the future & $1.69 \%$ \\
\hline $\begin{array}{l}\text { - Feeling shy/ feeling uncomfortable because of mixed } \\
\text { classes } \\
\text { - Not caring for education }\end{array}$ & $1.45 \%$ \\
\hline Dislike college & $1.21 \%$ \\
\hline $\begin{array}{l}\text { - } \quad \text { Cheating } \\
\text { - } \quad \text { Problem in understanding English } \\
\text { - } \quad \text { Not taking note in the classroom }\end{array}$ & $0.72 \%$ \\
\hline $\begin{array}{ll}\text { - } & \text { Leaving classroom when feel bored } \\
\text { - } & \text { Not following college rules } \\
\text { - } & \text { Improper attitude (not respecting teachers, } \\
\text { Laughing in classroom, quarreling with } \\
\text { classmate) } \\
\text { - } \quad \text { Doing something to make teacher angry } \\
\text { - } \quad \text { Spending too much time with friends } \\
\text { - } \quad \text { Change of life style because of living away } \\
\text { from family } \\
\text { - } \quad \text { Having no idea why he/she comes to college } \\
\text { Difficult exams }\end{array}$ & $0.48 \%$ \\
\hline $\begin{array}{ll}- & \text { Not taking subject/ course seriously } \\
- & \text { Memory problem } \\
- & \text { Lack of motivation } \\
- & \text { Having exam phobia } \\
- & \text { Low marks in exam } \\
- & \text { No timetable for daily life }\end{array}$ & $0.24 \%$ \\
\hline
\end{tabular}

As illustrated in the above table the main causes of poor performance pertain to students' 
failure to fulfill their academic responsibilities. For example, the first and foremost factor is, not studying or reviewing the material at home (16.50\%). When the lack of interest in studying is coupled with being absent and missing classes, the issue becomes worst. Not doing the required assignments at home, laziness, using mobile for playing games/texting, feeling sleepy in classroom because of staying late up at night, spending too much time with friends, not having an effective study schedule, dislike to come to college, having no plan for the future are among the main problems the students discussed in their essays.

Among the causes of poor performance, put forward by the students in their essays, is the problem with their major/ field of study. While some have no clear idea about their major and claim that it has been selected by the parents and it is not their choices, some find it too difficult to continue. Indeed, students often select a course with no idea about their capabilities and aptitude to learn a specific subject. Nevertheless, they need to be aware of their own development and adjust previous goals and decisions to accommodate personal growth.

Most students believe that their failure in college hinges on mastery of the English language. They may have difficulty in understanding teacher (majority of teachers at SCT are non-Omani) which causes students avoid asking/ answering question and/or participating in the classroom discussions. The point is that all specialized courses are taught in English. Thus, students need to be able to read, write, speak and listen to English effectively and being ineffective in one skill can lead to the academic failure.

Experiencing life away from home and family, establishing new relationships with peer groups inside and outside college, change of life style due to increased freedom are among the challenges students who have to leave their family and hometown and move to Salalah to continue their study are facing. The consequence of these changes is not always promising. Missing family and feel nostalgia, toxic friendships, misusing the freedom and wasting time are among the consequences of living away from family.

For some of the Students College is not really important. They may have heard/ known about the necessity of higher education but they do not really understand the value of education and its role in making their future. Having a look to the way students spend their time reveals that a small portion of their daily time is allotted to study and doing homework. Although they know that hard working and being studious is necessary for success in college, the priority for them is fun and spending time with friends.

Cheating in exam or copying assignments as a form of academic dishonesty has become common nowadays especially by the development of technology. Cheating could be done by searching for information on a mobile during exam or texting answers to another student which causes academic failure.

Boredom is another factor that has impact on students' performance. There could be many reasons for students' boredom such as, untouchable topics to read or write and mismatch between students' current level of knowledge and the presented material in the classroom. 


\subsubsection{Family-Related Factors}

Family plays a critical role in a student's academic performance. Family problems of different types are presented in Table 4.

Table 4. Summary of micro family-related factors for students poor performance

\begin{tabular}{lc}
\multicolumn{1}{c}{ Cause } & Percentage \\
\hline -uneducated parents & $80 \%$ \\
- big family & \\
- problem with parents & $6.66 \%$ \\
Parents have no idea how to treat/ bring up children & $4.44 \%$ \\
\hline - Divorced parents & \\
\hline - Poor family & $2.22 \%$ \\
\hline - Permissive parents/ no discipline & \\
\hline
\end{tabular}

Table 4 illustrates a summary of family problems which lead to students' low performance. The highest percentage ( $80 \%$ ) pertains to the problems of uneducated parents, big family and having problem with parents due to generation gap. Family encouragement plays a crucial role in children's educational success. It is obvious that when parents are uneducated, they have no idea about the value of education and they do not care about their children's performance, which causes the students lose their academic focus. In addition, too busy parents often do not care about the children's performance in school or college.

The daily distractions of life like family duties and work responsibilities are culprits in draining academic performance and must be managed properly. Living in a big family with six/ seven siblings around is a very common problem among SCT students which makes it difficult for them to focus on study and doing homework. In most cases, students as the elder brother/ sister has some responsibilities like taking care of younger siblings in the absence of parents, taking them to school and helping them in doing assignments. If the student is preoccupied by troubles at home or with friends, s/he may not be able to devote the necessary time and effort to accomplish his/her own tasks.

Another flaw with parents pertains to their attitude towards bringing up children. According to students' comments reflected in their writings, some parents do not have any idea about how to treat the children. They need to teach kids morals such as respect the teachers and others in the society.

Furthermore, the poor financial condition of the family because of the parental death or divorce can distract a student from academics because survival becomes a more immediate and pressing priority. 


\subsubsection{Teacher-Related Factors}

Professional qualifications are important in education. Qualified teacher is an essential ingredient for students' success. The role a teacher plays in student's performance is undeniable. There is a fact that when things go wrong in the area of academics, teachers are always blamed. In other words, in most cases teachers are responsible for students' low achievements. Table 3 shows the factors that pertain to the role of teachers in the failure of the SCT students as mentioned in their essays.

Table 3. Summary of teacher-related factors

\begin{tabular}{rcc}
\hline \multicolumn{1}{c}{ Cause } & percentage \\
\hline Disqualified/incompetent teacher & $68.96 \%$ \\
\hline$-\quad$ Boring teacher & $6.89 \%$ \\
\hline$-\quad$ Teacher's behavior/ manner & $3.44 \%$ \\
\hline$\quad$ Noffective teaching methodology & \\
\hline & Lack of knowledge about the subject & \\
\hline
\end{tabular}

To a large extent, the issues students blame teachers for their low performance pertains to the way they teach and present the subject. According to Omani students, some teachers do not explain the lesson clearly, they do not help students when they need, do not give homework to practice the taught material and do not emphasize on the important points. Among the factors that make a teacher incompetent in teaching are experience and passion. For example, inexperienced teacher or a teacher with no passion for teaching is unable to help students to get comprehensive idea of the subject matter. A teacher's skill in presenting material, engaging students in classroom discussions and encouraging students in doing assignments contributes to the deep comprehension of the given topic. Professional qualifications are important in education. The professional skill of the teacher 'establishes a productive classroom atmosphere from the start by means of good organization and carefully planned teaching structures' (Farrant, 1980, p. 169). In addition, some teachers have classroom management problem which may lead to extreme authoritarianism or vice versa uncontrollable classroom atmosphere which in turn hinder fruitful class discussions and collaborative learning (Note 1).

\subsubsection{Other Factors}

Besides the factors discussed above, there are other reasons for SCT students' poor college performance. Table 5 shows these factors. 
Table 5. Summary of other causes of students' poor performance

\begin{tabular}{lc}
\hline \multicolumn{1}{c}{ Cause } & Percentage \\
\hline Bad friend & $56.86 \%$ \\
\hline Financial problem & $15.68 \%$ \\
\hline Health problem & $13.72 \%$ \\
\hline$-\quad$ Marriage & $3.91 \%$ \\
$-\quad$ Transportation problem & $1.96 \%$ \\
\hline - Smoking & \\
\hline & Working while attending at college \\
\hline
\end{tabular}

Given the fact that a friend can affect our life in one way or another, making friends with bad people and their influence on SCT students' poor performance has the highest percentage among the other factors. Among the negative effects of toxic friendship are; negative attitude toward college and education, disrespect teachers, smoking and dismissing lessons.

Despite the fact that SCT is a public college under MOM supervision and students do not have to pay any tuition, financial problem is among the issues discussed by the students in their essays. Cooper and Stewart (2013) believe that "Money in early childhood makes most difference to cognitive outcomes, while in later childhood and adolescence it makes more difference to social and behavioral outcomes". A study by Sum and Fogg (1991) emphasizes the correlation between poverty and students achievement. In their study, poor students' achievement ranked $19^{\text {th }}$ percentile on assessments whereas students from a mid-upper income families ranked $66^{\text {th }}$ percentile on assessments (Cited in Lacour1 \& Tissington, 2011). The impact of low income on the welfare of family directly/indirectly may lead to low performance when family is unable to provide a peaceful atmosphere for children and facilities like car.

The negative association between smoking and academic achievement has been studied by different institutions. The results of a survey by National Youth Risk Behavior in 2009 show that students with higher grades are less likely to engage in smoking than their classmates with lower grades, and students who do not engage in smoking receive higher grades than their classmates who smoke. Smoking is a big problem among male students at SCT. It is a typical behaviour of SCT male students to leave class for smoking.

\section{Concluding Remarks}

Education is a significant facet of human development. Psychologically poor academic performance not only leads to learner's low self-esteem, but also causes stress to the parents.

In Oman, due to insufficient effort to pass elementary and high school, students are not prepared for the academic demands of the college. During primary and high school students often spend a minimum time for studying. New college students often come into class expected that college courses will function the way their HS courses did. But as soon as they 
enroll for college, they find out that they have to work hard. Thus, they need to change their study habits to pass the courses successfully.

In an educational setting where the goal is to "get a degree" instead of "to become educated" the path is easy and can be achieved with the least effort. A student may get high marks but might simply not care enough about education to exert the effort. Improving passing standards in a way that only qualified students can pass exams would be of great help. In this way students have to put forth more effort because the expectations have been increased.

Absenteeism, lateness and irregular college attendance are certain factors that are believed to be responsible for general poor academic performances. As a consequence, students are unable to catch up with what was taught in class and are always behind. Thus, the strict rules for frequent absences should be followed without any exceptional case and flexibility.

In addition, Omani students need to be encouraged to use English as they converse with their classmates in and out classroom. The more they use English in their daily communications, the broader the range of vocabulary will be. It helps them to understand non- Omani teachers and the textbooks.

The findings of the current study contributes to come to some conclusions among them are: 1) students need to understand subject matter they are taught, 2) tasks needs to be localized culturally, 3) students need to be present in class regularly, 4) college rules and regulations should be strict and 5) the competitive environment could be conducive and stimulating for surface learners to motivate them to reflect on their learning and spend more time for learning. Bearing in mind that there is a positive relationship between doing homework and learning outcomes, teachers need to assign homework that is related to the learning objectives. Homework should be assigned regularly in reasonable amounts, well explained, collected, reviewed and provided with feedback for students (Butler, 1987). Moreover, parent- teacher meetings are needed to follow up students' performance.

Last but not least, the "get a diploma" mission does not lead to academic excellence. An internalized desire for learning is prerequisite if we wish learning to take place. Besides all these factors, there are many other factors that influence academic performance of students on various levels. Being a student, achieving success can become an impossible task if s/he get caught up by these factors and make no efforts to overcome.

\section{References}

Al-Mahrooqi, R. and Denman, C. (2015). Issues in English Education in the Arab World. Cambridge Scholars Publishing. UK.

Al-Issa, A.(2009b). Omani ELT school curriculum: Policy \& practice. Paper presented in the Oman Annual International ELT Conference, The Language Centre, Sultan Qaboos University, Muscat.

Cascio, C. (2015). Factors of Poor Student Performance. Retrieved September 20, 2015, from http://classroom.synonym.com/factors-poor-student-performance-12636.html 


\section{Macrothink}

Copper, K., \& Stewart, K., (2013). Does money affect children's outcome? Retrieved September 26, 2015, from https://www.jrf.org.uk/report/does-money-affect-children\%E2\%80\%99s-outcomes

Karande S., \& Kulkarni, M. (2005). Poor school performance. Indian Journal of Pediatr, 72(11), 961-7. http://dx.doi.org/10.1007/BF02731673

Lacour, M., \& Tissington, L. D. (2011). The effects of poverty on academic achievement. Educational Research and Reviews, 6(7), 522-527,

Mbugua, Z. K., Komen, K., Muthaa, G. M., \& Nkonke, G. R., (2012). Factors Contributing To Students' Poor Performance in Mathematics at Kenya Certificate of Secondary Education in Kenya: A Case of Baringo County, Kenya. American International Journal of Contemporary Research, 2(6), 87-91.

Rahamneh, K. F. A., (2012). Reasons for the Low Academic Achievements among the Students of the Main Stages in Selected Schools in the Province of Al-Balqa. Ozean Journal of Social Sciences, 5(1), 31-40.

SiqueiraI, C. M., \& Juliana Gurge-GiannettiII, J., (2011). Poor school performance: an updated review. Revista da Associação Médica Brasileira, 5(1), 78-86.

Online resource. Tobacco Use and Academic Achievement. (n.d.). Retrieved February 19, 2016, from http://www.cdc.gov/healthyyouth/health_and_academics/pdf/tobacco_use.pdf

\section{Notes}

Note 1. As a teacher who has been teaching at SCT for the past four years and being confident that SCT teachers are highly qualified and are observed frequently by HOC, the author rechecked the essays in which the teachers were blamed for the failure to find any relationship between unhappy students and their overall performance in the exam. The result showed that in most cases it was weak students who blamed teachers for being disqualified and incompetent.

\section{Copyright Disclaimer}

Copyright for this article is retained by the author(s), with first publication rights granted to the journal.

This is an open-access article distributed under the terms and conditions of the Creative Commons Attribution license (http://creativecommons.org/licenses/by/3.0/). 